\title{
Probiotics for experimental obesity prevention: focus on strain dependence and viability of composition
}

\author{
Probiotyki jako eksperymentalna metoda zapobiegania otyłości: wpływ liczby \\ podawanych szczepów bakteryjnych i ich żywotności
}

\author{
Nazarii Kobyliak', Tetyana Falalyeyeva ${ }^{2}$, Tetyana Beregova², Mykola Spivak ${ }^{3}$ \\ ${ }^{1}$ Endocrinology Department, Bogomolets National Medical University, Kyiv, Ukraine \\ ${ }^{2}$ Educational and Scientific Centre «Institute of Biology» Taras Shevchenko National University of Kyiv, Ukraine \\ ${ }^{3}$ Interferon Department of Zabolotny Institute of Microbiology and Virology, National Academy of Sciences of Ukraine
}

\begin{abstract}
Introduction: A comparative animal study of the efficacy of intermittent short-course administration of lyophilised single-, three-, and live multistrain probiotic on obesity.

Methods: We included 70 rats divided into seven groups $(\mathrm{n}=10$ in each). Rats of group I were intact. Newborn rats of groups II-VII were injected with monosodium glutamate (MSG) $(4 \mathrm{mg} / \mathrm{g}$ ). Rats of group II (MSG-obesity group) were untreated. The group III-V received lyophilised monoprobiotics B. animalis VKL, B. animalis VKB, and L. casei IMVB-7280, respectively. Group VI received the mix of these three probiotic strains. Group VII was treated with multiprobiotic "Symbiter", which contains 14 live probiotic strains (Lactobacillus, Bifidobacterium, Propionibacterium, Acetobacter genera).

Results: Neonatal treatment with MSG caused stunted growth, which is why, despite the lack of weight gain dynamics and absence of significant food consumption rate and body weight changes at day 120, we noted the development of obesity in all MSG-obesity rats and in up to $20-70 \%$ after probiotic administration. Supplementation of probiotic composition, with preference to live strains, led to a significantly lower prevalence of obesity, and reduction of VAT weight and serum lipid levels as compared to single-strain probiotic. In our comparative single-strain analysis a trend towards more pronounced hypolipidaemic effect and VAT weight reduction was observed for lyophilised L. casei IMVB-7280 as compared to B. animalis VKL and VKB strains.

Conclusions: Multistrain formed mutualistic interactions in mixtures and therefore able to share with different metabolites, affect different receptors and produced various of biologically active compounds which synergistic overall effect greater than the sum of the single effects. (Endokrynol Pol 2017; 68 (6): 659-667)
\end{abstract}

Key words: obesity, lyophilised and alive probiotic strains, Lactobacillus, Bifidobacterium, multistrain probiotics

\section{Streszczenie}

Wstęp: Badania porównawcze na zwierzętach oceniające skuteczność w zapobieganiu otyłości podawania w krótkotrwałych cyklach liofilizowanych preparatów zawierających jeden, trzy lub więcej żywych szczepów probiotycznych.

Materiał i metody: Do badania włączono 70 szczurów podzielonych na 7 grup ( $\mathrm{n}=10 \mathrm{w}$ każdej grupie). Szczury w grupie I nie zostały poddane żadnej interwencji. Noworodkom szczurów w grupach II-VII wstrzyknięto glutaminian jednosodowy (monosodium glutamate, MSG) (4 mg/g). U szczurów z grupy II (z otyłością indukowaną MSG) niż stosowano żadnego leczenia. Szczury w grupach III-V otrzymywały liofilizowane probiotyki, odpowiednio B. animalis VKL, B. animalis VKB i L. casei IMVB-7280. Grupie VI podawano mieszankę tych trzech szczepów. W grupie VII stosowano wieloskładnikowy preparat probiotyczny „Symbiter” zawierający 14 żywych szczepów (Lactobacillus, Bifidobacterium, Propionibacterium, Acetobacter).

Wyniki: Podanie szczurzym noworodkom MSG spowodowało zahamowanie wzrostu, jednak mimo wolniejszego przyrostu masy ciała i braku istotnych zmian wielkości spożycia karmy i masy ciała po 120 dniach zaobserwowano rozwój otyłości u wszystkich szczurów z otyłością indukowaną MSG i u 20-70\% zwierząt otrzymujących probiotyki. Podawanie kompozycji probiotyków, szczególnie żywych szczepów, prowadzi do istotnego zmniejszenia częstości występowania otyłości, ilości tkanki tłuszczowej trzewnej i stężania lipidów w surowicy w porównaniu ze stosowaniem preparatów jednoszczepowych. W analizie porównawczej preparatów jednoskładnikowych stwierdzono tendencję w kierunku silniejszego działania hipolipemicznego i większej redukcji tkanki tłuszczowej trzewnej w przypadku liofilizowanego szczepu L. casei IMVB-7280 niż szczepów B. animalis VKL i VKB.

Wnioski: $W$ preparatach wieloszczepowych powstają wzajemne interakcje umożliwiające wymianę różnych metabolitów, wpływ na różne receptory i produkcję różnych biologicznie czynnych cząsteczek, których ogólny efekt synergistyczny jest większy niż suma efektów jednostkowych. (Endokrynol Pol 2017; 68 (6): 659-667)

Słowa kluczowe: otyłość, liofilizowane i żywe szczepy probiotyczne, Lactobacillus, Bifidobacterium, probiotyki wieloszczepowe 


\section{Introduction}

Overweight and obesity are defined as abnormal or excessive fat accumulation that may impair health. The worldwide prevalence of obesity more than doubled between 1980 and 2014, and for today the World Health Organisation has declared obesity as a global epidemic and has taken it under control. In 2014, more than 1.9 billion adults older than 18 years (39\%) are overweight. Overall, about $13 \%$ or 600 million of the adult population (11\% of men and $15 \%$ of women) are obese [1].

The most frequent cause that leads to obesity development is an imbalance between energy intake and energy expenditure. In this complex process genetic susceptibility, and environmental and lifestyle factors are involved. Current research efforts have focused on host and environmental factors that may affect energy balance [2].

Recent studies have revealed a whole new insight into obesity, suggesting a link between intestinal microbes and weight gain [3]. Authors suggest that gut microbiota are involved in the control of body weight, energy homeostasis, and inflammation, and thus play a role in the pathophysiology of obesity [4]. Dietary variation and caloric intake induce changes in gut microbiome composition, selectively promoting the growth of certain microbes [5]. These gut microbes thrive and impact the host metabolism by affecting inflammation and fat storage [6, 7].

Prebiotics and probiotics are of interest because they have been shown to alter the composition of gut microbiota and to affect food intake, appetite, body weight, and composition as well as metabolic functions through gastrointestinal pathways and modulation of the gut bacterial community [8]. At present, the question of the probiotics' influence on lipid metabolism and obesity is actively debated in the scientific literature [9-11].

The importance of microbiota modification in the conditions of obesity has been confirmed by numerous studies of the probiotic interventions. The analysis of more than 20 articles from 2013 to July 2014 by Cani et al. showed that at least 15 different strains of Lactobacillus and two strains of Bifidobacterium do not equally influence on body weight, fat mass, glucose metabolism, inflammatory markers, plasma and hepatic lipids, and plasma cholesterol levels [12].

In our previous work, we showed the development of non-alcoholic fatty liver disease (NAFLD) under conditions of the severe visceral obesity induced by neonatal administration of monosodium glutamate (MSG) [13]. Thus, the obtained results confirmed the validity of the usage of MSG for NAFLD development. Moreover, short-term courses of multiprobiotic cocktails lead to significant reduction of hepatic steatosis, total lipids, and triglycerides content in the liver, as well as preventing the development of NAFLD in animals, as compared to MSG-obesity littermates. More pronounced changes were observed after administration of probiotic mixture preferably containing alive strains as compared to lyophilised cocktails; our data also suggest failure of NAFLD prevention with monoprobiotic strains [14]. Based on this suggestion, it was interesting to compare the influence of the of mono-strain and probiotic compositions in lyophilised or live conditions in the prevention and treatment of obesity. Therefore, the aim of the current work was a comparative animal study of the efficacy of intermittent short-course administration of lyophilised single-, three-, and live multistrain probiotic on the development of obesity.

\section{Materials and methods}

\section{Ethics Statement}

This study was carried out in strict accordance with the recommendations in the Guide for the Care and Use of Laboratory Animals of the National Institutes of Health and the general ethical principles of animal experiments, approved by the First National Congress on Bioethics, Ukraine (September 2001). The protocol was approved by the Committee on the Ethics of Animal Experiments of Taras Shevchenko National University of Kyiv (Protocol number: 6/2015). The rats were kept in collective cages in controlled conditions of temperature $\left(22 \pm 3^{\circ} \mathrm{C}\right)$, light (12-h light/dark cycle), and relative humidity $(60 \pm 5 \%)$.

\section{Study design}

We included 70 newborn Wistar male rats, divided into seven groups of 10 animals (Fig. 1). Group 1 intact rats were administered neonatally with hypertonic saline $(1.25 \mathrm{mg} / \mathrm{g}$ body weight per day, control group) subcutaneously (s.c.) on the $2^{\text {nd }}, 4^{\text {th }}, 6^{\text {th }}, 8^{\text {th }}$, and $10^{\text {th }}$ postnatal days. All newborn rats except controls were injected with monosodium glutamate - MSG ( $4 \mathrm{mg} / \mathrm{g}$ body weight per day) on the $2-10^{\text {th }}$ days of life, to induced obesity [15]. Six pups per mother were standardised to ensure better lactation. After the weaning, one-month-old MSG-treated animals were randomly divided into six groups, treated and untreated with probiotics. From weaning (four weeks) to 120 days of age, rats had free access to standard rodent chow (PurinaW) and water during the entire experimental period.

Group II (MSG-obesity) received $2.5 \mathrm{ml} / \mathrm{kg}$ of water (intragastrically). Group III-V received lyophilized monoprobiotics $B$. animalis $V K L, B$. animalis $V K B, L$. casei $I M V B-7280$ at a dose of $50 \mathrm{mg} / \mathrm{kg}\left(5 \times 10^{9} \mathrm{CFU} / \mathrm{kg}\right)$, 


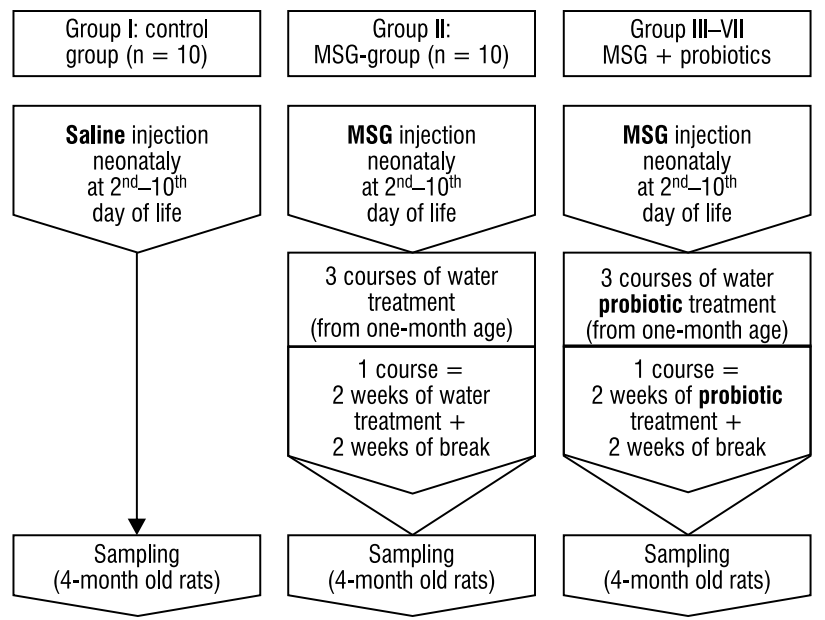

Figure 1. The design of the study. Three arrows with the corresponding signs demonstrate experimental groups of animals and the manipulation within these groups

Rycina 1. Projekt badania. Trzy strzałki z odpowiednimi oznaczeniami odpowiadaja grupom eksperymentalnym zwierząt oraz działaniom prowadzonym w obrębie tych grup

respectively. Group VI received $2.5 \mathrm{ml} / \mathrm{kg}$ of an aqueous solution of a mixture of the three probiotic strains (2:1:1 Lactobacillus casei IMVB-7280, Bifidobacterium animalis $V K L$, Bifidobacterium animalis $V K B$ ) at a dose of $50 \mathrm{mg} / \mathrm{kg}$ $\left(5 \times 10^{9} \mathrm{CFU} / \mathrm{kg}\right)(\mathrm{g})$ (intragastrically). Group VII was treated with multiprobiotic "Symbiter" containing a biomass of 14 live probiotic strains (Lactobacillus + Lactococcus $\left[6 \times 10^{10} \mathrm{CFU} / \mathrm{g}\right]$, Bifidobacterium $\left[1 \times 10^{10} / \mathrm{g}\right]$, Propionibacterium $\left[3 \times 10^{10} / \mathrm{g}\right]$, Acetobacter $\left.\left[1 \times 10^{6} / \mathrm{g}\right]\right)$ at a dose of $140 \mathrm{mg} / \mathrm{kg}\left(1.4 \times 10^{10} \mathrm{CFU} / \mathrm{kg}\right)$. The multiprobiotic "Symbiter" was supplied by Scientific and Production Company "O.D. Prolisok". The treatment with probiotics was started at the age of one month and had been performed for three months in 2 two-week courses (one course per month). All parameters were measured in four-month-old rats.

\section{Anthropometric measurements and obesity parameter assessment}

During four months, in all groups, the changes in body weight and food intake were analysed. In adult age, rats from the three experimental groups $(\mathrm{n}=70)$ were weighed and killed by cervical dislocation under urethane anaesthesia. We dissected and weighed visceral adipose tissue (VAT) (epididymal, perirenal, and omental fat).

For each animal at month four of life (120 days) we determined the existence of obesity using the Lee index. It was calculated as follows: the cube root of body weight $(\mathrm{g}) /$ naso-anal length $(\mathrm{cm})[16,17]$. Rats presenting values higher than 0.300 were classified as obese, and equal to or less than 0.300 as normal [18].

\section{Sample collection and blood biochemistry analysis}

Rats of all groups were fasted for approximately 12 hours prior to sacrifice. Blood was collected into a microcentrifuge tube containing a mixture of $\mathrm{NaF}$ and EDTA in a $2: 1(\mathrm{w} / \mathrm{w})$ ratio, centrifuged for $10 \mathrm{~min}$ at $1000 \mathrm{~g}$, followed by selection of serum. Cholesterol, triglycerides, high-density lipoprotein (HDL), low-density lipoprotein (LDL), and very-low-density lipoproteins (VLDL) in serum were determined by standard biochemical methods. Lipid extraction from liver was performed according to Folch et al. [19].

\section{Statistical analysis}

Statistical analysis was performed using SPSS-20 software. All data in this study were expressed as mean \pm standard error $(\mathrm{M} \pm \mathrm{SEM})$ or percentage. Data distribution was analysed using the Kolmogorov-Smirnov normality test. Continuous variables with parametric distribution were analysed using Analysis of Variance (ANOVA), and if the results were significant, a post-hoc Turkey's test was performed. For data with non-parametric distribution, Kruskall-Wallis and post-hoc Tukey's test were conducted for multiple comparisons. For comparisons of categorical variables we conducted a $\chi^{2}$ test. The difference between groups was defined to be statistically significant when a p-value was less than 0.05 .

\section{Results}

Figure 2A presents weight gain dynamics of the different experimental groups. Initial assessments of body weight were performed before administration of probiotic started at 30-days of life. In this time point the lowest body weight was observed in intact rats, which was significant as compared to all other groups. At day 60 and after one month of probiotic administration there were no significant changes in body weight between intact and both lyophilised (VI) and live (VII) poliprobiotic groups. However, we observed significantly lower weight in these three groups as compared to MSG-obesity and after single-strain (III-V) probiotic correction, respectively. Later, in terms of 90 and 120 days, body weight flattened, and at the end of experiment the weight of all rats did not differ significantly (Fig. 3A). Also, we did not find significant changes in food consumption rates between all groups at each time point (Fig. 2B).

Neonatal treatment with MSG caused stunted growth, which is one of the main characteristic features of this experimental obesity model. In our study animals of group II-VII were characterised by significantly smaller naso-anal length compared to intact rats (Fig 3B). That is why, despite the lack of 

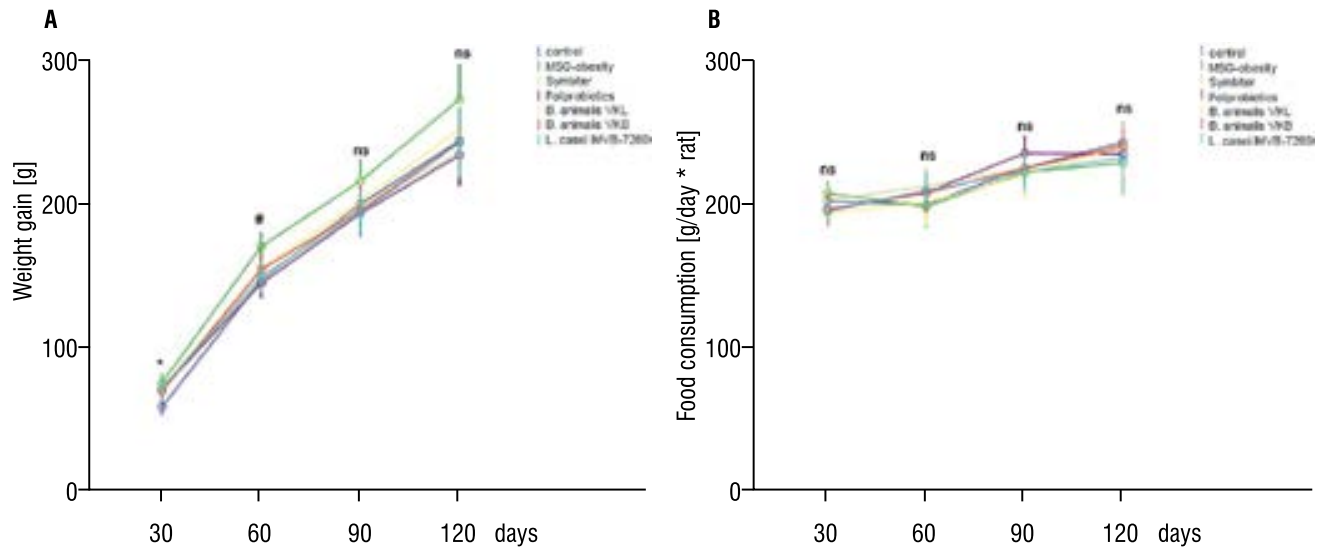

${ }^{*} \mathrm{p}<0.05$ between control and all others groups

$\# p<0.05$ between control poli-, multiprobiotic groups verssus MSG-obesity and all single-sterin probiotic groups

Figure 2. Weight dynamics and food consumption rate in experimental animals

Rycina 2. Zmiany masy ciała a spożycie karmy w grupie obserwowanych zwierząt
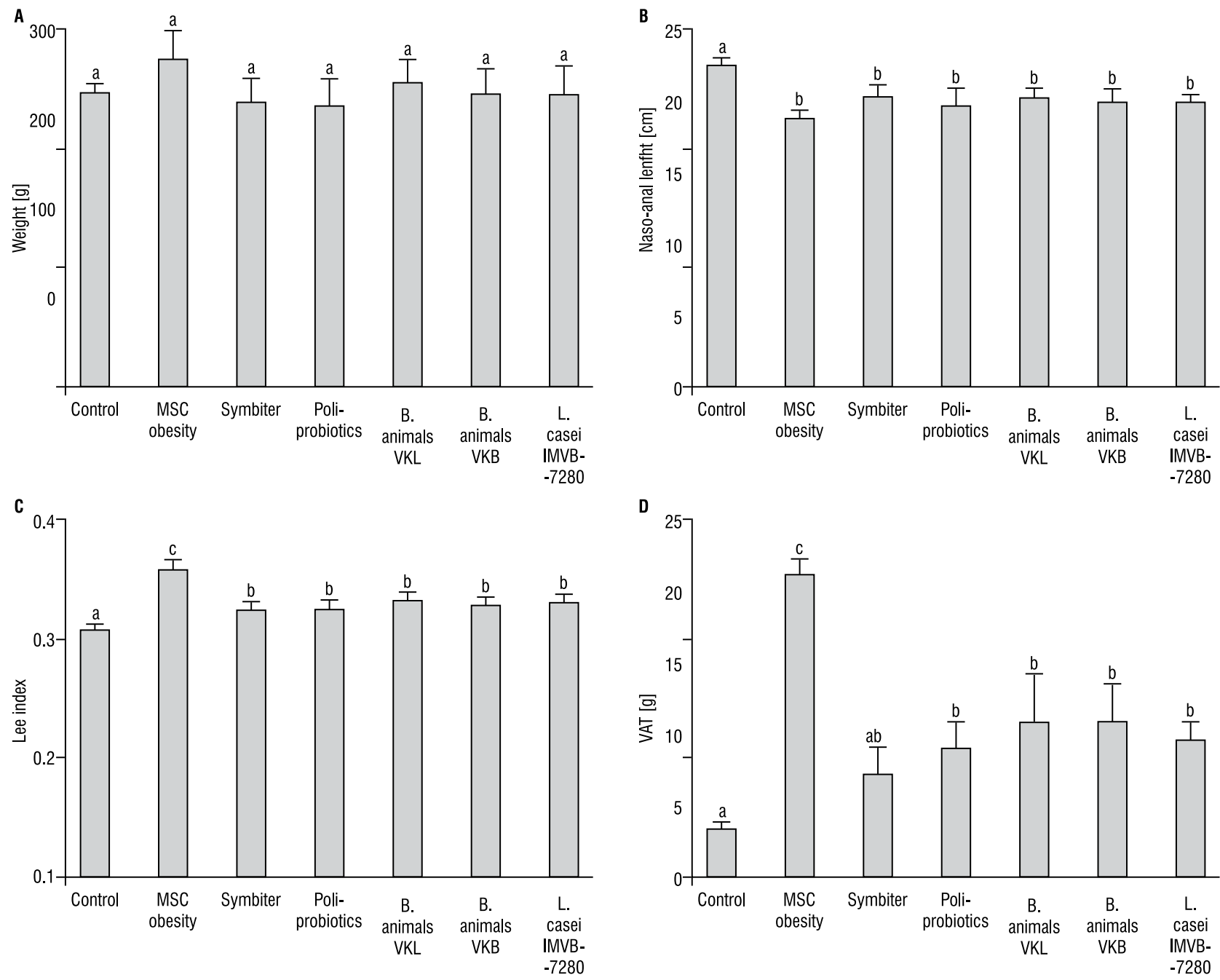

Figure 3. Anthropometric parameters in 4-month-old rats in the condition of MSG-induced obesity and after probiotic administration ( $\boldsymbol{A}$ - body weight; $\boldsymbol{B}$ - naso-anal length; $\boldsymbol{C}$ - Lee index; $\boldsymbol{D}$ - visceral adipose tissue weight). Data are presented as the $M \pm S E M$. One-way ANOVA with post hoc Tukeys test for multiple comparisons were performed for data analysis. ${ }^{a, b, c}$ Values at the same row with different superscript letters shows significant differences in $p<0.05$

Rycina 3. Parametry antropometryczne 4-miesięcznych szczurów z otyłością indukowaną MSG i po stosowaniu probiotyków (A masa ciata, B - dtugość nosowo-odbytnicza, $\boldsymbol{C}$ - wskaźnik Lee, D - masa tkanki ttuszczowej trzewnej) 


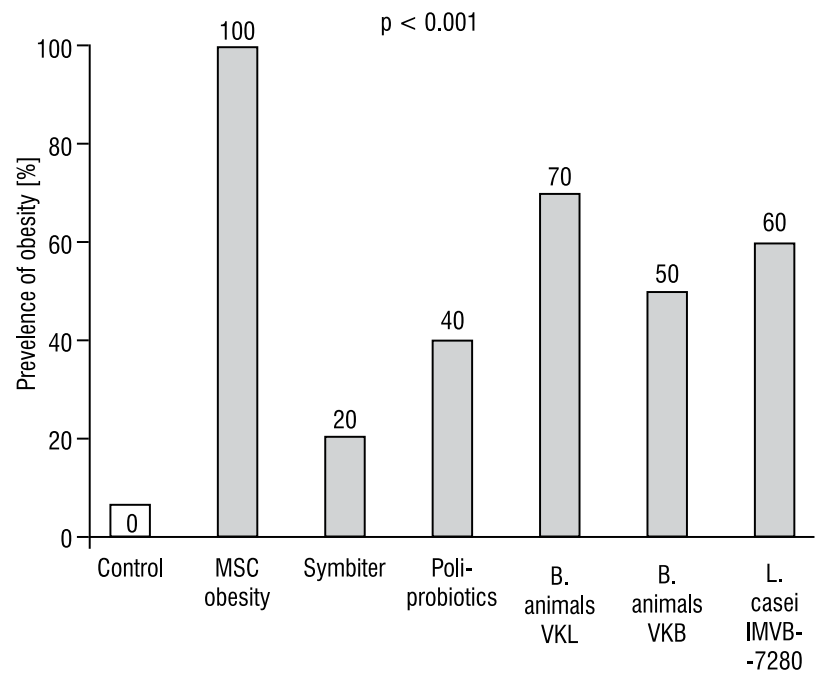

Figure 4. Prevalence of obesity (\% rate) in 4-month-old rats in the condition of MSG-induced obesity and after probiotic administration

Rycina 4. Częstość występowania otyłości (\%) u 4-miesięcznych szczurów z otyłościa indukowanej MSG i po stosowaniu probiotyków

weight gain dynamics and absence of significant body weight changes at day 120 , we noted $100 \%$ development of obesity in MSG-obesity rats and up to $70 \%$ after probiotic administration, which was significantly higher compared to intact animals $(\mathrm{p}<0.001)$, where obesity was not found (Fig. 4). On the other hand, it should be noted that administration of probiotic cocktails led to a significantly lower prevalence of obesity as compared to single-strain probiotic groups (III-V). The maximum preventive effect was described for the live multiprobiotic Symbiter group (VII), in which development of obesity was seen in only $20 \%$ of rats (Fig. 4).

The obtained results were fully confirmed by the Lee index, in which values more than 0.300 were used to confirm obesity in rats. The average value of the Lee index in MSG-obesity rats was $0.343 \pm 0.006$, which was significantly higher as compared to intact animals $(0.276 \pm 0.008, \mathrm{p}<0.001)$ (Fig. 3C). The preventive effect of probiotics was confirmed by significantly lower Lee index in all probiotic groups as compared to MSG-obesity. On the other hand, correction with probiotics did not provoke significant recovery of the Lee index to the intact rats' value (Fig. 3C). Although we did not notice significant probiotics intergroup differences according to Lee index value, the most important decreases were observed for both poliprobiotic groups (group VI $-0.298 \pm 0.005$ and group VII $-0.298 \pm 0.004)$.

We found that neonatal MSG administration led to the development of severe abdominal obesity. The total
VAT weight in rats from MSG-obesity group was 16.93 $\pm 0.43 \mathrm{~g}$ that in 6.2 times higher as compared to intact rats $(\mathrm{p}<0,001)$ (Fig 3D).

The administration of probiotics led to significant reduction of VAT accumulation for all interventional groups as compared to the MSG-obesity group ( $\mathrm{p}<$ 0.001). Differences between these groups were insignificant; nevertheless, according to viability and strain dependence of probiotic composition, certain preventive features were noted. The lowest total VAT weight was measured after correction with alive multiprobiotic "Symbiter" (group VII). Only for this probiotic composition we did not observed significant difference on VAT weight as compared to intact rats $(5.79 \pm 0.75 \mathrm{~g}$ vs. 2.72 $\pm 0.2 \mathrm{~g}, \mathrm{p}=0.112$ ) (Fig. 3D, 5).

Changes of total VAT weight in monocomponent probiotic groups (III-V) detected a strain-specific trend to a more pronounced visceral fat accumulation reduction with probiotic based on lyophilised $L$. casei $I M V B-7280$ as compared to B. animalis VKL and VKB strains (Fig. 3D).

It is well known that obesity is characterised by lipid metabolism changes. The administration of probiotics carried a significant strain-dependent effect on lipid metabolism in experimental animals (Fig. 6). The most pronounced lipid-lowering effects were observed for the live poliprobiotic group (group VII). The use of "Symbiter" led to a significant reduction of serum TG and total cholesterol on $46.4 \%$ ( $p<0.001$ ) and $26.1 \%$ ( $p<0.001)$, respectively, as compared to MSG-obesity (Fig. 6A, C). Moreover, lipid concentration restored almost to the level of intact rats, which was accompanied by a lack of significant difference between these experimental groups.

Interestingly, that single-strain L. casei IMVB-7280 probiotic led substantially to the same as in group VII: significant reduction of TG level on 44.1\% ( $p<0.001)$ as compared to MSG-obesity (Fig. 6A). As well as the Symbiter group, a statistically significant difference between monocomponent group and intact rats was absent $(\mathrm{p}=0.100)$. However, as compared to group VII, use of L. casei IMVB-7280 did not demonstrate the same total cholesterol lowering effect (Fig. 6C).

Poliprobiotic lyophilised (group VI) and single-strain probiotics containing B. animalis $V K L$ and $V K B$ (Group III-IV) also had a slight hypolipidaemic effect, which resulted in significant reduction of total cholesterol and TG as compared MSG-obesity, but this effect did not reach the level of intact animals (Fig. 6A, C).

After treatment with probiotics the serum level of LDL was the same and on average significantly decreased by $20-30 \%$ as compared to the MSG-obesity group (Fig. 6D). Differences between all interventional groups (III-VII) and intact rats were insignificant. 

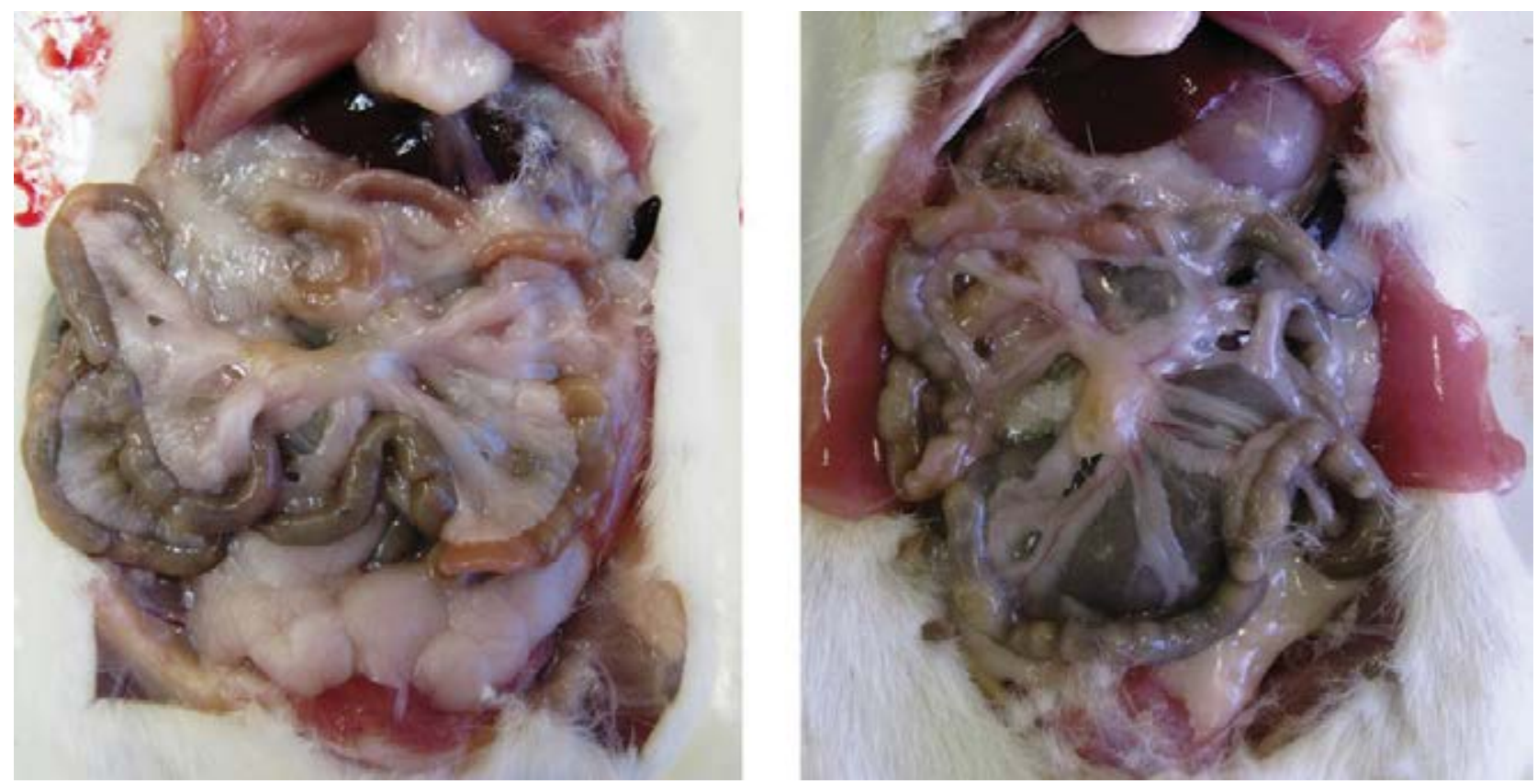

Figure 5. Original photos of visceral adipose tissue mass in 4-month-old rats in the condition of MSG-induced obesity and after administration of alive probiotic composition (group VII)

Rycina 5. Oryginalne fotografie przedstawiające tkankę tłuszczową trzewna u 4-miesięcznych szczurów z otyłością indukowaną MSG i po stosowaniu kompozycji żywych szczepów probiotycznych (grupa VII)

The HDL level did not change significantly after single-strain probiotics (group III-V) as compared to MSG-obesity. For poliprobiotic groups, regardless of strain activity, we noted a tendency to increase HDL levels by $20-25 \%$ (Fig. 6B). However, despite the moderate effectiveness, biochemical parameters of lipid metabolism were not normalised to the level of the intact rats.

\section{Discussion}

Preclinical evidence supporting the "anti-obesity" effects of probiotics comes mainly from studies on singlestrain probiotics belonging to the Lactobacillus and Bifidobacterium genera, which are common inhabitants of the human intestinal ecosystem. Also, most of the current research aimed at providing weight management through probiotic administration thus far has been conducted in animal models of diet-induced obesity.

Several studies carried out on high-fat diet (HFD) or high-sucrose diet (HSD) induced obesity in mice when administered or supplemented for more than eight weeks with one or a number of Lactobacillus strains such as Lactobacillus plantarum LG42 [20], L. gasseri BNR17 [21], L. gasseri SBT2055 [22], Lactobacillus curvatus HY7601, and L. plantarum KY1032 [23] accompanied by significant reduction in weight gain and VAT mass and a relatively lowered level of serum and liver lipid contents, parallel to reduced expression of lipogenic genes
(ACC1, FAS, SREBP-1, LXR- $\alpha$ ), whereas it increased the hepatic PPAR- $\alpha, \mathrm{UCP} 2$, and CPT-1 mRNA levels, which upregulate the expression of enzymes involved in fatty acid oxidation. Therefore, data obtained on the genetic-determined models of obesity are still ambiguous. On the one hand, dietary supplementation with Lactobacillus gasseri NT significantly decreased VAT weight and TG in the liver in KK-A(y) mice on a high-fat diet via reduction of lipid digestion/absorption [24]. On the other hand, Hamad et al., when assessing the effect of probiotic L. gasseri SBT2055 supplementation, observed a decrease in mesenteric fat weight, adipocyte sizes, and both serum and liver cholesterol contents only in lean rats as compared to obese Zucker rats. However, an increased excretion of faecal fatty acids and total neutral faecal sterols in both rat strains was observed [25].

Strain-dependent anti-obesity effect of different Lactobacillus containing probiotics were well exemplified in Fak and Backhed's study. In a mouse model of obesity (Apoe-/- mice) three strains of L. reuteri: ATCC PTA 4659 (ATCC), DSM 17938 (DSM), and L6798, were tested when supplemented to HFD for eight weeks, for the anti-obesity, anti-inflammatory, and anti-atherogenic effects. They found that only L. reuteri ATCC gained significantly less body weight than the control mice, whereas the L6798 mice gained significantly more. L. reuteri strain ATCC PTA 4659 partly prevented diet-induced obesity, via induction of liver expression of Cpt1; 

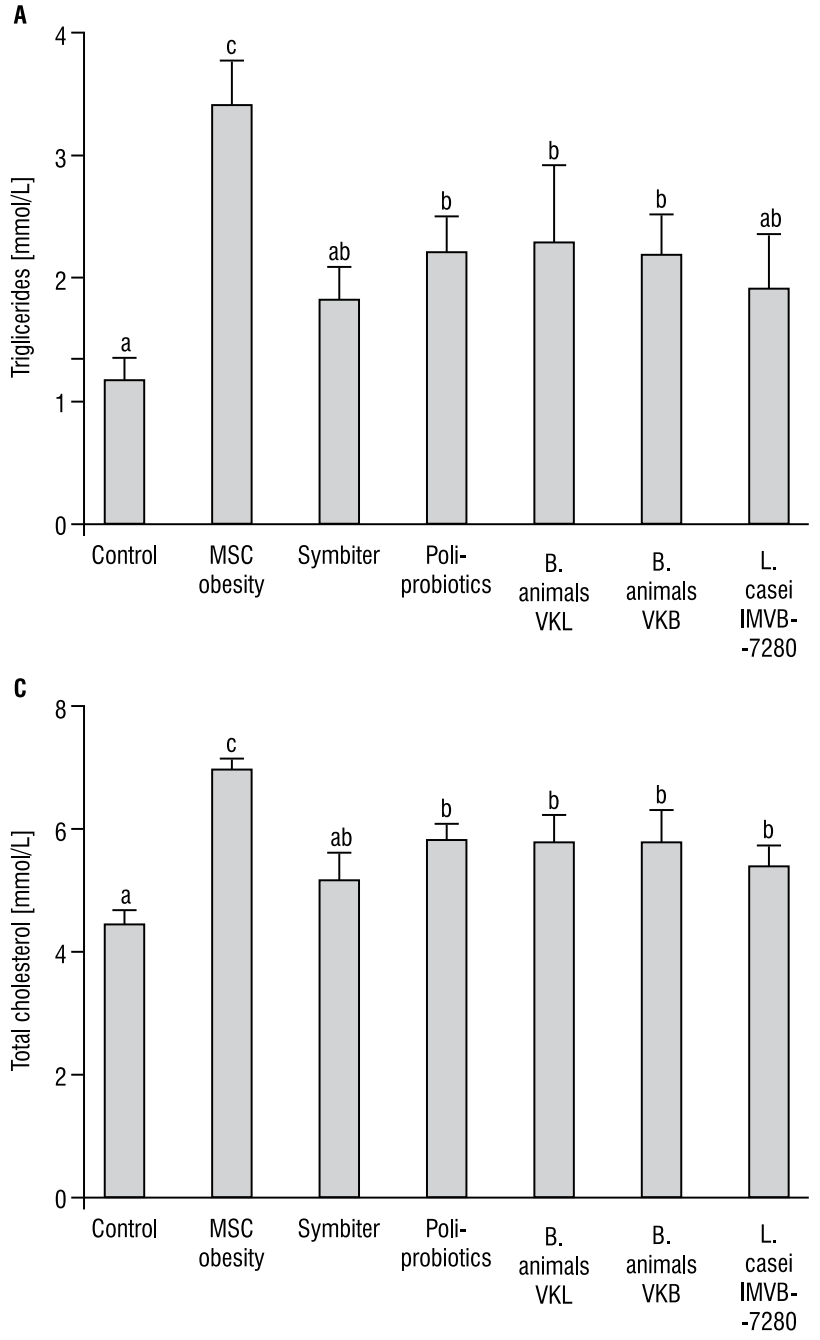
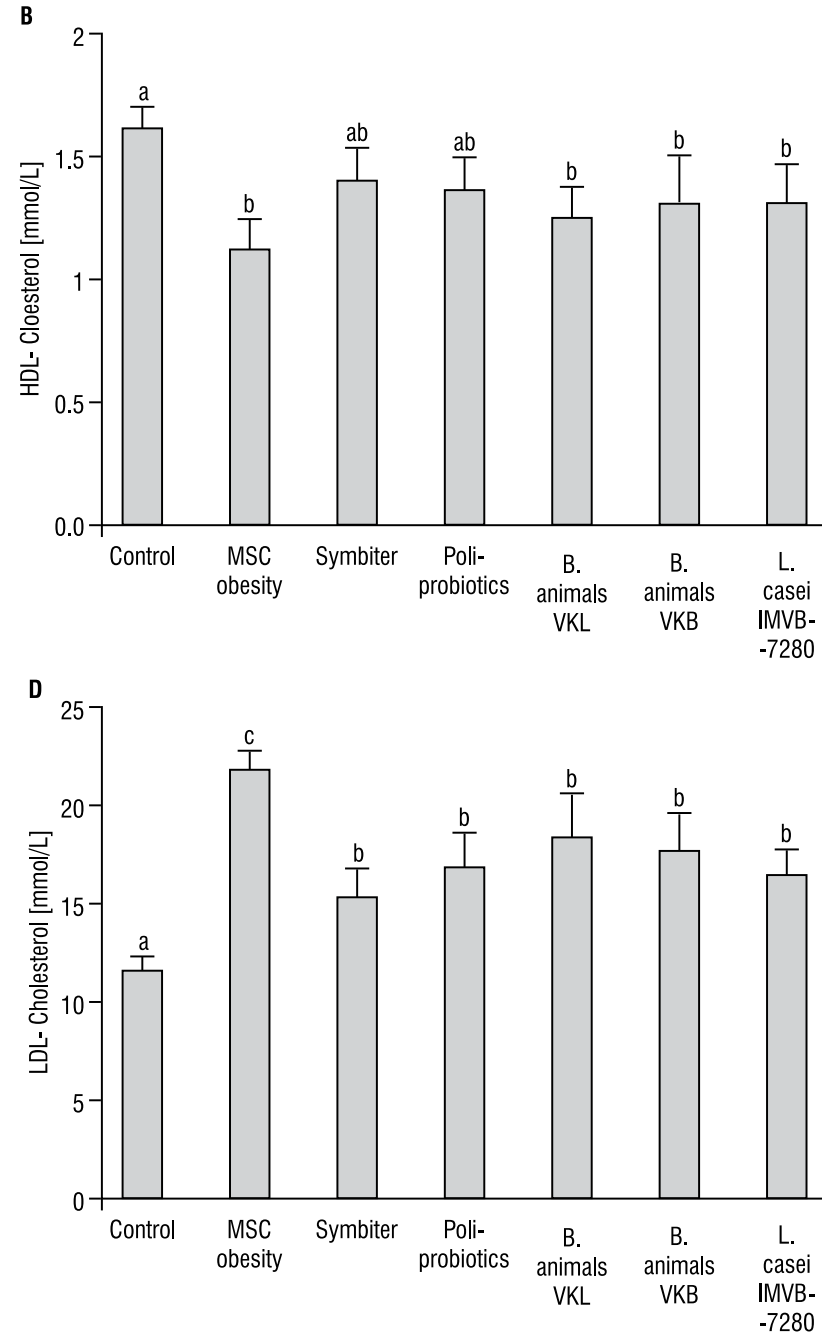

Figure 6. Serum lipids levels in 4-month-old rats in the condition of MSG-induced obesity and after probiotic administration (Atriglycerides; $\boldsymbol{B}-\mathrm{HDL}$-cholesterol; $\boldsymbol{C}$ - total cholesterol; $\boldsymbol{D}-L D L$-cholesterol). Data are presented as the $M \pm S E M$. One-way ANOVA with post hoc Tukeys test for multiple comparisons was performed for data analysis. ${ }^{a, b, c}$ Values in the same row with different superscript letters show significant differences in $p<0.05$

Rycina 6. Stężenie lipidów w surowicy 4-miesięcznych szczurów z otyłością indukowaną MSG i po stosowaniu probiotyków (A triglicerydy; $\boldsymbol{B}$ - cholesterol frakcji HDL; $\boldsymbol{C}$ - cholesterol catkowity; $\boldsymbol{D}$ - cholesterol frakcji LDL)

however, no anti-inflammatory or anti-atherosclerotic effect was achieved irrespective of the treatment [26].

It is well known that diet is one of the most influential factors for altering microbiota composition, so in contrast to the majority of other studies, which used high-fat diets for the study of the effects of probiotics, we used MSG-induced obesity models in rats, which were characterised by severe visceral obesity and stunted growth. Also, it is worth noting that different effects have been observed depending on the strain used, and the action of the probiotics is tightly connected with the properties and viability of each strain. Therefore, as compared to similar studies with single-strain fashion, we first compared the influence of the of lyophilised mono-strain and probiotic compositions in lyophilised or live conditions in the development of obesity.
It was established that intermittent short-term courses of probiotic administration started from 30 days of life had different amounts and strain-dependent anti-obesity effects. Neonatal treatment with MSG caused stunted growth, which is why, despite the lack of weight gain dynamics and absence of significant food consumption rate and body weight changes at day 120 , we noted $100 \%$ development of obesity in MSG-obesity rats and up to $20-70 \%$ after probiotic administration. Supplementation of probiotic composition, with preference to live strains, led to a significantly lower prevalence of obesity, and reduction of VAT weight and serum lipid levels as compared to single-strain probiotic groups (III-V).

At least partly, similarly to our design, a study that focused on comparative analysis, but in single-strain 
fashion, were reported. It has recently been reported that 12-week dietary supplementation with either Lactobacillus paracasei CNCM I-4270, Lactobacillus rhamnosus I-3690, or Bifidobacterium animalis subsp. lactis I-2494 significantly attenuated HFD-induced weight gain despite no reductions in food intake in mice [27]. Similar results have been obtained in studies where Bifidobacterium spp. (B. pseudocatenulatum SPM 1204, B. longum SPM 1205, and B. longum SPM 1207 [28], B. adolescentis [29], B. breve B-3 [30], B. lactis 420 [31]) was added to a HFD in rats. In the study by Yin et al., rats with HFD-induced obesity were treated with four strains of Bifidobacteria (L66-5, L75-4, M13-4, and FS31-12). Namely, B L66-5 blunted the dietinduced increase in body weight, while B M13-4 further enhanced it. Whereas no differences in relative body fat content were found among treatments. Therefore, all four strains were associated with reductions in serum and liver TG, and significantly alleviated lipid deposition in liver. Only Bifidobacterium L66-5 and Bifidobacterium FS3112 decreased cholesterol liver content significantly [32].

In our comparative single-strain probiotic analysis a trend towards more pronounced hypolipidaemic effect and VAT weight reduction was observed for lyophilised L. casei IMVB-7280 as compared to B. animalis VKL and $V K B$ strains. Furthermore, L. casei IMVB-7280 led substantially to the same as for the live multiprobiotic group (VII): a significant reduction of TG level.

The number of microbial species found in the gut is huge, and the interactions among them and with the host cells need to be further explained so that probiotic strains can be used with a rationale [33]. Preclinical studies have been conducted that used different bacterial strains, animal models, and lengths of administration. Nearly all studies have shown some anti-obesity property of probiotics. However, despite a large body of evidence supporting the anti-obesity and favourable metabolic effects of probiotics, it should be borne in mind that these effects may vary dramatically, depending both on the bacterial strain and on the host [2].

\section{Conclusions}

Administration from childhood of probiotic composition, with a preference to live strains, led to a significantly lower prevalence of obesity, and reduction of VAT weight and serum lipid levels as compared to singlestrain probiotic groups (III-V). It may be related to more pronounced viability of live strains and their prevention of bacterial translocation. Multistrain or multispecies formed mutualistic interactions in mixtures and therefore were able to share with different metabolites, affect different receptors, and produced various biologically active compounds which synergistic overall effect greater than the sum of the single effects.

\section{Acknowledgments}

The authors would like to express sincere thanks to Dr. Yankovsky Dmitro Stanislavovych for supporting this research.

\section{Author contributions}

All the authors have accepted responsibility for the entire content of this submitted manuscript and approved its submission.

\section{Financial support}

None declared.

\section{Competing interests}

The funding organisation(s) played no role in the study design; in the collection, analysis, and interpretation of data; in the writing of the report; or in the decision to submit the report for publication.

\section{References}

1. World Health Organization Obesity. http://www.who.int/topics/obesity/ en/ (26 June 2015).

2. Kobyliak N, Conte C, Cammarota G, et al. Probiotics in prevention and treatment of obesity: a critical view. Nutr Metab (Lond). 2016; 13: 14, doi: 10.1186/s12986-016-0067-0, indexed in Pubmed: 26900391.

3. Wolf KJ, Lorenz RG. Gut Microbiota and Obesity. Curr Obes Rep. 2012 1(1): 1-8, doi: 10.1007/s13679-011-0001-8, indexed in Pubmed: 23106036.

4. Kobyliak N, Virchenko O, Falalyeyeva T. Pathophysiological role of host microbiota in the development of obesity. Nutr J. 2016; 15: 43, doi: 10.1186/s12937-016-0166-9, indexed in Pubmed: 27105827.

5. Tilg H, Kaser A. Gut microbiome, obesity, and metabolic dysfunction. J Clin Invest. 2011; 121(6): 2126-2132, doi: 10.1172/JCI58109, indexed in Pubmed: 21633181.

6. Catalán V, Gómez-Ambrosi J, Ramirez B, et al. Proinflammatory cytokines in obesity: impact of type 2 diabetes mellitus and gastric bypass. Obes Surg. 2007; 17(11): 1464-1474, doi: 10.1007/s11695-008-9424-z, indexed in Pubmed: 18219773.

7. Bäckhed F, Ding H, Wang T, et al. The gut microbiota as an environmental factor that regulates fat storage. Proc Natl Acad Sci U S A. 2004; 101(44): 15718-15723, doi: 10.1073/pnas.0407076101, indexed in Pubmed: 15505215

8. Sanchez M, Panahi S, Tremblay A. Childhood obesity: a role for gut microbiota? Int J Environ Res Public Health. 2014; 12(1): 162-175, doi: 10.3390/ijerph120100162, indexed in Pubmed: 25546278

9. Kobyliak N, Falalyeyeva T, Bodnar P, et al. Probiotics Supplemented with Omega-3 Fatty Acids are More Effective for Hepatic Steatosis Reduction in an Animal Model of Obesity. Probiotics Antimicrob Proteins. 2017; 9(2): 123-130, doi: 10.1007/s12602-016-9230-1, indexed in Pubmed: 27660157.

10. Kim SW, Park KY, Kim B, et al. Lactobacillus rhamnosus GG improves insulin sensitivity and reduces adiposity in high-fat diet-fed mice through enhancement of adiponectin production. Biochem Biophys Res Commun. 2013; 431(2): 258-263, doi: 10.1016/j.bbrc.2012.12.121, indexed in Pubmed: 23313485.

11. Luoto R, Laitinen $K$, Nermes $M$, et al. Impact of maternal probioticsupplemented dietary counseling during pregnancy on colostrum adiponectin concentration: a prospective, randomized, placebocontrolled study. Early Hum Dev. 2012; 88(6): 339-344, doi: 10.1016/j. earlhumdev.2011.09.006, indexed in Pubmed: 21945174.

12. Cani PD, Van Hul M. Novel opportunities for next-generation probiotics targeting metabolic syndrome. Curr Opin Biotechnol. 2015; 32: 21-27, doi: 10.1016/j.copbio.2014.10.006, indexed in Pubmed: 25448228.

13. Kondro M, Mykhalchyshyn G, Bodnar P, et al. Metabolic profile and morpho-functional state of the liver in rats with glutamate-induced obesity. Curr Issues Pharm Med Sci. 2013; 26(4): 379-381, doi: 10.12923/j.2084980x/26.4/a.05.

14. Kobyliak N, Falalyeyeva T, Virchenko O, et al. Comparative experimental investigation on the efficacy of mono- and multiprobiotic strains in non-alcoholic fatty liver disease prevention. BMC Gastroenterol. 2016; 16: 34, doi: 10.1186/s12876-016-0451-2, indexed in Pubmed: 26976285. 
15. Kobyliak N, Abenavoli L, Falalyeyeva T, et al. Prevention of NAFLD development in rats with obesity via the improvement of pro/antioxidant state by cerium dioxide nanoparticles. Clujul Med. 2016; 89(2): 229-235, doi: 10.15386/cjmed-632, indexed in Pubmed: 27152074.

16. Novelli ELB, Diniz YS, Galhardi CM, et al. Anthropometrical parameters and markers of obesity in rats. Lab Anim. 2007; 41(1): 111-119, doi: 10.1258/002367707779399518, indexed in Pubmed: 17234057.

17. Bernardis LL, Patterson BD. Correlation between 'Lee index' and carcass fat content in weanling and adult female rats with hypothalamic lesions. J Endocrinol. 1968; 40(4): 527-528, doi: 10.1677/joe.0.0400527, indexed in Pubmed: 4868415.

18. Savcheniuk O, Kobyliak N, Kondro M, et al. Short-term periodic consumption of multiprobiotic from childhood improves insulin sensitivity, prevents development of non-alcoholic fatty liver disease and adiposity in adult rats with glutamate-induced obesity. BMC Complement Altern Med. 2014; 14: 247, doi: 10.1186/1472-6882-14-247, indexed in Pubmed 25030027.

19. Folch J, Lees M, Sloane Stanley GH. A simple method for the isolation and purification of total lipides from animal tissues. J Biol Chem. 1957 226(1): 497-509, indexed in Pubmed: 13428781.

20. Park JE, Oh SH, Cha YS. Lactobacillus plantarum LG42 isolated from gajami sik-hae decreases body and fat pad weights in diet-induced obese mice. J Appl Microbiol. 2014; 116(1): 145-156, doi: 10.1111/jam.12354, indexed in Pubmed: 24131682.

21. Kang JH, Yun SI, Park MH, et al. Anti-obesity effect of Lactobacillus gasseri BNR17 in high-sucrose diet-induced obese mice. PLoS One. 2013; 8(1): e54617, doi: 10.1371/journal.pone.0054617, indexed in Pubmed: 23382926.

22. Miyoshi M, Ogawa A, Higurashi S, et al. Anti-obesity effect of Lactobacillus gasseri SBT2055 accompanied by inhibition of pro-inflammatory gene expression in the visceral adipose tissue in diet-induced obese mice. Eur J Nutr. 2014; 53(2): 599-606, doi: 10.1007/s00394-013-0568-9, indexed in Pubmed: 23917447.

23. Park DY, Ahn YT, Park SH, et al. Supplementation of Lactobacillus curvatus HY7601 and Lactobacillus plantarum KY1032 in diet-induced obese mice is associated with gut microbial changes and reduction in obesity. PLoS One. 2013; 8(3): e59470, doi: 10.1371/journal.pone.0059470, indexed in Pubmed: 23555678.
24. Yonejima Y, Ushida K, Mori Y. Lactobacillus gasseri NT decreased visceral fat through enhancement of lipid excretion in feces of KK-A(y) mice. Biosci Biotechnol Biochem. 2013; 77(11): 2312-2315, doi: 10.1271/ bbb.130488, indexed in Pubmed: 24200800.

25. Hamad EM, Sato M, Uzu K, et al. Milk fermented by Lactobacillus gasseri SBT2055 influences adipocyte size via inhibition of dietary fa absorption in Zucker rats. Br J Nutr. 2009; 101(5): 716-724, doi: 10.1017/ S0007114508043808, indexed in Pubmed: 18684338.

26. Fåk F, Bäckhed F. Lactobacillus reuteri prevents diet-induced obesity, but not atherosclerosis, in a strain dependent fashion in Apoe-/- mice. PLoS One. 2012; 7(10): e46837, doi: 10.1371/journal.pone.0046837, indexed in Pubmed: 23056479 .

27. Wang J, Tang $\mathrm{H}$, Zhang $\mathrm{C}$, et al. Modulation of gut microbiota during probiotic-mediated attenuation of metabolic syndrome in high fat dietfed mice. ISME J. 2015; 9(1): 1-15, doi: 10.1038/ismej.2014.99, indexed in Pubmed: 24936764.

28. An HMi, Park SY, Lee DoK, et al. Antiobesity and lipid-lowering effects of Bifidobacterium spp. in high fat diet-induced obese rats. Lipids Health Dis. 2011; 10: 116, doi: 10.1186/1476-511X-10-116, indexed in Pubmed: 21745411

29. Chen J, Wang R, Li XF, et al. Bifidobacterium adolescentis supplementation ameliorates visceral fat accumulation and insulin sensitivity in an experimental model of the metabolic syndrome. Br J Nutr. 2012; 107(10): 1429-1434, doi: 10.1017/S0007114511004491, indexed in Pubmed: 21914236.

30. Kondo S, Xiao JZ, Satoh T, et al. Antiobesity effects of Bifidobacterium breve strain B-3 supplementation in a mouse model with high-fat dietinduced obesity. Biosci Biotechnol Biochem. 2010; 74(8): 1656-1661, doi: 10.1271/bbb.100267, indexed in Pubmed: 20699581.

31. Stenman LK, Waget A, Garret C, et al. Potential probiotic Bifidobacterium animalis ssp. lactis 420 prevents weight gain and glucose intolerance in diet-induced obese mice. Benef Microbes. 2014; 5(4): 437-445, doi 10.3920/BM2014.0014, indexed in Pubmed: 25062610.

32. Yin YN, Yu QF, Fu N, et al. Effects of four Bifidobacteria on obesity in high-fat diet induced rats. World J Gastroenterol. 2010; 16(27): 3394-3401, doi: 10.3748/wjg.v16.i27.3394, indexed in Pubmed: 20632441.

33. Nova E, Pérez de Heredia F, Gómez-Martínez S, et al. The Role of Probiotics on the Microbiota: Effect on Obesity. Nutr Clin Pract. 2016; 31(3) 387-400, doi: 10.1177/0884533615620350, indexed in Pubmed: 26869611. 